UDK 339(497.5:497.4)“14“(091)

94(497.4 Štajerska)“14“

Primljeno: 17. 9. 2018.

Prihvaćeno: 24. 10. 2018.

Izvorni znanstveni rad

DOI: $10.22586 /$ pp.v55i0.38

\title{
Trade of Croatian Lands with the Cities of the Slovenian Styria ${ }^{* * 1}$
}

The aim of this article is to analyse the presence of merchants from the Croatian lands in the towns of Slovenian Styria, based on the archival sources and scholarly literature. The study is meant as the first contribution to the research on the economic and political relations between individuals from the Croatian and Slovenian territories.

Keywords: Slovenian Styria, Croatia, Medieval Towns, Medieval Trade, Maribor, Ptuj

The city is marked by trade. ${ }^{2}$ Such a deliberately exaggerated assertion, which consciously sets aside all other urban (administrative-judicial, cultural activities, etc.) activities which, in addition to the core activities of trading and craftsman-

Tone Ravnikar, Faculty of Arts, University of Maribor, Koroška 160, 2000 Maribor, Slovenia, E-mail: anton.ravnikar@um.si

** This research was conducted within the framework of the project URBES funded by the Croatian Science Foundation under no. IP-2014-09-7235.

1 The aim of this paper is to examine and analyze the possible presence of merchants from Croatian lands in the cities of Slovenian Styria, based on the archives of the Slovenian Styrian cities. To this end, the (Archives of the Republic of Slovenia, Regional Archive Maribor, Historical Archive Ptuj, Historical Archives of Celje) and Austria (Steiermärkisches Landesarchiv Graz; Östereichisches Staatsarchiv: Haus-, Hof- und Staats Archiv Wien) were examined. The topic is interesting and largely unexplored. There is little attention paid to the study of Croatia's inland trade with the West also in the latest synthetic presentation of the medieval history of Croatia of 2003, in the creation of which the most eminent Croatian medievalists participated; in the Chapter on trade, the trade of Venetian cities, of Dubrovnik, and of the inland cities with the Adria is researched, but there is no mention of the trade with the West (Povijest Hvata. Srednji vek (ed. Franjo Šanjek), Zagreb 2003, p. 275 et seq. and p. 403 et seq.). In order to get a comprehensive picture, it will be necessary to examine the material of Croatian and Hungarian archives, which is why this paper is to be understood primarily as the first step towards the study of commercial contacts between Styria and Croatia.

2 Dušan Kos, Kdor z mestom ne trpi naj se z mestom ne krepi (Ljubljana: Ministrstvo za kulturo, Uprava Republike Slovenije za kulturno dediščino, 1998) (hereinafter: Kos, Kdor se z mestom). 
ship, are an inseparable part of every city's characteristics and character, is the main focus of the article; trading of the citizens will be studied in the documents attesting to the medieval activities in the territory of today's Slovenian Styria. More specifically, commercial contacts between the Slovenian Styrian cities and the cities of the present-day Croatia, their establishment, frequency and, in particular, the concrete individuals who maintained those contacts will be highlighted in the article, whereas other significant issues, e.g. the creation of the cities, their common and individual characteristics, the differences between inland cities in the German Kingdom and the cities in the Hungarian kingdom, their layout, architectural features, the relations between the cities and (especially) the local nobility, etc. ${ }^{3}$ will be omitted. This is mainly because the aim of this short article is not that ambitious; it is merely to start a discussion about concrete contacts of concrete individuals traveling along this utmost important strategic trade transport route from the West to the East. When referring to the characteristics that best denote the city and the citizens, trade and commercial activities, in addition to monetization, are the ones that mark the city most and distinguish it from its surroundings. Ideally, the city is artisans and merchants; in medieval towns, the members of these two branches were considered citizens, while other inhabitants were usually viewed as guests, aliens, and non-residents. However, there always existed big status and wealth differences between traders and artisans. The former were perceived as nobles, and wealthy as a rule, while the latter were viewed as making their living with physical work. Although there were

\footnotetext{
3 In Slovenian historiography, a series of debates has been published, which address and resolve many of these issues. It is necessary to mention in particular the great opus of Sergij Vilfan dedicated to medieval cities, such as: Sergius Vilfan, Pravna zgodovina Slovencev (od naselitve do zloma stare Jugoslavije) (Ljubljana: Slovenska matica, 1961, reprint in 1996); Sergius Vilfan, "Die mittelalterliche Stadt zwischen Pannonien und der Nordadria; Binnen- und Küstenstädte im slowenischen Raum", in: Internationales kulturhistorisches Symposium Mogersdorf, Band 4 (Szombathely, 1974), 125-141; Sergius Vilfan, "Stadt und Adel. Ein Vergleich zwischen der Oberen Adria und Pannonien”, in: Die Stadt am Ausgang des Mittelalters (Linz; Donau: Österreichischer Arbeitskreis für Stadtgeschichtsforschung, 1974), 63-74; Sergius Vilfan, "Zgodovina mest med krajevnim in primerjalnim zgodovinopisjem”, Kronika, časopis za krajevno zgodovino 25 (1977), no. 3: 157-159. In recent times, Miha Kosi systematically has been systematically dealing with the issues of the cities; let me mention some of his works: Miha Kosi, "Nastanek mesta Gorica - dileme in nove perspektive", Kronika 55 (2007), no. 2: 171-184; Miha Kosi, Potujoči srednji vek. Cesta, popotnik in promet na Slovenskem med antiko in 16. stoletjem (Ljubljana: ZRC SAZU, Založba ZRC, 1998), Miha Kosi, "Predurbane ali zgodnjeurbane naselbine? (civitas Pettovia, Carnium/Creina in druga centralna naselja v zgodnjem srednjem veku, I. del”, Zgodovinski časopis 59 (2005): 269-331, II. del in: Zgodovinski časopis 63 (2009), Miha Kosi, "Začetki mesta Slovenj Gradec. Prispevek k nastanku mest na jugovzhodnem Koroškem v srednjem veku”, Kronika 56 (2008), no. 2: 131-164; Miha Kosi, "Začetki Škofje Loke in freisinški škofje kot ustanovitelji mest (Primerjalna študija k nastanku mest na Kranjskem v srednjem veku)", in: Blaznikov zbornik (Ljubljana; Škofja Loka: Založba ZRC, ZRC SAZU; Muzejsko društvo, 2005). Jože Curk addressed Styrian towns in the Middle Ages (Mesta in trgi na slovenskem Štajerskem. Urbanogradbeni oris do začetkov 20. stoletja, Maribor 1991 and the references ibid). The listed works serve as an introduction to the study of the problems of the cities and townspeople in the Middle Ages; otherwise, many more related works could be cited.
} 
major differences between individual artisanship branches, traders was placed among the bourgeois elite due to their activities. However, the practice may differ from the theory, and, quite often, it does differ considerably.

Most cities in the area of Slovenian Styria, which provides the geographical framework of the article, were small or at least of a smaller size. This assertion applies not only to the area under consideration but also to the entire territory of Slovenia (and also beyond). ${ }^{4}$ In this territory, some cities could be classified as medium-sized towns, whereas the majority of them were small cities, i.e. the cities with a maximum of 2,000 inhabitants and most of them had fewer than 1,000 inhabitants. However, one should not be mislead by this fact and upfront attribute less importance to the cities than they really had despite their smallness. The power of bourgeois settlements did not stem from the size of the settlement, but from the density of the network of urban settlements. According to Paolo Santonino in the 15th century, in not more than a few hours of moderate horse riding one could reach any city. ${ }^{5}$

In this brief review, we are going to confine ourselves to the cities that emerged in the area of the Slovenian Styria and their commercial contacts with the East, i.e. the Croatian lands, since the author does not feel to be competent to extend the research to the entire area of today's Slovenia.

Therefore, let me first define the scope and content of the paper discussion. The term "Slovenian Styria" was totally wrong and artificial to be used in the context of the Middle Ages (and not only for this period of time). The term is taken from a modern political vocabulary that could only be created after 1918. Thus, it can only be used as a cursor to determine the geographical scope to be addressed. In this context, an additional problem emerged. It must be borne in mind that in the researched area at least two different regions should be addressed. Although at this point I would not like to delve into the entire problematics of the emergence of medieval lands, or more specifically, of the region of Styria, I must very briefly and, therefore, only generally notice that in the area of today's "Slovenian Styria," there were two (in modern political speech described as) separate areas in the Middle Ages: the Savinja region (the Savinja March) and the Podravje region (which belonged to the Carantanian March and the March of Styria, respectively), which formally became parts of one land as late as in 1311; thus, the Styrian history was conditionally uniform in its reference to the area of the present-day Slovenian Styria only from that period onwards ${ }^{6}$. Even so, it is necessary to pinpoint the fact that both regions remained separated from each other throughout

\footnotetext{
4 Kos, Kdor $z$ mestom, 27 et seq.

5 Kos, Kdor se $z$ mestom, 12.

${ }_{6}$ Peter Štih, Vasko Simonitti, Na stičišču svetov (Ljubljana: Modrijan 2009) (hereinafter: Štih-Simonitti, Na stičišču), and references ibid.
} 
the whole Middle Ages, and that this separation increased due to the activities of the Counts of Celje. ${ }^{7}$ The Mislinja Valley and the city of Slovenj Gradec should actually be considered as a separate area; the city of Slovenj Gradec was swinging between Styria and Carinthia in the considered period, and had a specific history from time to time. Nevertheless, in the paper the entire area of today's Slovenian Styria will be focused on, bearing in mind the given duality of the area, and taking into account the emerging differences.

The first difference to observe is the topographical difference between the two regions. In the Podravje region, 5 or 6 cities emerged in the Middle Ages (Ptuj, Slovenj Gradec (which is classified in the Podravje region for the transparency purpose), (conditionally Radgona - the medieval city on the Austrian side of the border today), Maribor, Slovenska Bistrica and Ormož), while in the Savinja region only two cities (Brežice (which can conditionally be classified in the so-called Savinja region) and Celje) emerged. Almost identical is the number of medieval markets. In the Savinja region, 22 markets were set up in the Middle Ages, while 23 markets were set up in the Podravje region. Altogether, there were 7 cities and 45 markets. ${ }^{8}$ This large number of markets (the city-to-market ratio was 1: 1.4 in Carniola, and as much as 1: 4.5 in Styria; in the Slovenian Styria this ratio was even 1: 6.1, which was exactly the same as in Lower Austria), certainly has a different background. However, it certainly showed a big role (certainly bigger than in Carniola) and great power assumed by individual landlords and Styrian citizens, whereby it is necessary to recall the early formation of the Styrian provincial consciousness in the provincial nobility in relation to the replacement of the provincial dukes in 1192, and, as a consequence the first reference to the Styrian provincial law (that was first mentioned in 1186 in the Georgenberg Pact), ${ }^{9}$ all of which contributed to strengthening the confidence of the Styrian citizens and to their independence, which was also reflected in the massive set up of markets. As a rule, cities could only be established by princes, while markets (could be) were the institutions of noble families. The difference between the Savinja region and the Podravje region, which is shown in the ratio between the medieval cities and the markets, was definitely the result of their different historical developments in the $12^{\text {th }}$, and, especially in the 13th century. Whereas it can be established that two high-ranking nobles who had the right to establish cities dominated with their properties in the Podravje region: the Salzburg Archdiocese with Ptuj and Ormož, and the Provincial prince with Maribor,

\footnotetext{
7 About the Land of Celje see: Peter Štih, "Celjski grofje, vprašanje njihove deželnoknežje oblasti in dežele celjske”, in: Grafenauerjev zbornik, ed. Vincenc Rajšp et all. (Ljubljana: Slovenska akademija znanosti in umetnosti; Znanstvenoraziskovalni center SAZU; Filozofska fakulteta v Ljubljani; Pedagoška akademija v Mariboru, 1996), 227-256.

8 Topographical data are taken from: Curk, Trgi in mesta na slovenskem Štajerskem.

9 Cf: Karl Spreitzhofer, Georgenberger Handfeste. Entstehung und Folgen der ersten Verfassungsurkunde der Steiermark (Graz : Verlag Styria, 1986).
} 
Slovenska Bistrica, Slovenj Gradec and Radgona, East of Maribor, in the Savinja region after the death of its last border inhabitants there was not a single noble with a property and of a sufficiently high rank that would allow setting up cities; instead, there were many feudalists that established various centres - markets, each in their respective area, which lead to a large number of markets, as well as to a relatively small number of cities. Brežice, as a Salzburg institution, was established as a market probably as early as in the 13th century (for the first time it was indirectly mentioned as such in 1309 ${ }^{10}$ and before 1322 it was granted the city rights by the Archbishop mainly because of its border location and a greater need for strengthening security, i.e. the need for the city fortification.

The Archbishop firmly held the city administration in Brežice - in the extensive document from 1353, ${ }^{11}$ issued by Archbishop Ortolf to Brežice, no city council, the municipality of the townspeople, or any other self-governing body is mentioned. However, it was found out that the city judge was appointed by the Archbishop or his deputy in Leibnitz. ${ }^{12}$ Celje nevertheless gained the city status formally as late as in the 15th century (Celje will be briefly discussed below).

It should be pointed out that when reference is to contacts of places in Styria with other places (cities, markets), it would be historically incorrect to limit those only to the area of today's Slovenian Styria. Most of the territory now viewed as Slovenian Styria was at that time naturally and politically linked to the rest of the (northern, German ...) Styria. This connection (political, commercial, of settlements, etc.) was even more strengthened since the second half of the twelfth century, when the Land of Styria was formed; from then onwards the parts that had been separated politically (in terms of property) were more firmly connected through the Provincial Prince to one whole. The exception is the southern part of the "Slovenian Styria," the former Savinja March, which is one of the two political and geographical areas that are the subject of this paper.

At least as important as political connections in the promotion of trade and other connections between the North and the South was the improved road across the Semmering pass, where in 1160 the Ottokar III, Margrave of Styria, erected a hospital, with the view to build a road across the pass ${ }^{13}$ by monks. It was only

10 1309, Urbarium of Salzburg for Brežice and Sevnica (after: Norbert Weiss, Das Städtewesen dr Ehemaligen Untersteiermark im Mittelalter (Graz: Im Selbstverlag der Historischen Landeskommission für Steiermark, 2002) dalje kot: Weiss, Das Städtewesen), "Nicolaus civis de Rain."

11 1353, May 18, transcript in: StLA Graz, št.: 2473e. Regest v: Weiss, Das Städtewesen.

12 Cf: Tone Ravnikar, "Mestne elite v srednjeveških Brežicah in Sevnici”, in: Mestne elite v srednjem in zgodnjem novem veku med Alpami, Jadranom in Panonsko nižino, ed. Janez Mlinar, Bojan Balkovec (Ljubljana: Zveza Zgodovinskih Društev Slovenije, 2011), p. 250 et seq. Albert Muchar, Geschichte des Herzogthums Steiermark VI. (Graz, 1859), 327 et seq.

13 1160, UBSt I, No. 406, 394-396. Othmar Pickl, "Handel und Verkehr in der Steiermark zur Zeit der Traungauer”, in: Das Werden der Steiermark, ed. Gerhard Pferschy (Graz; Wien; Köln: Styria, 1980) (dalje kot: Pickl, Handel und Verkehr), 339. 
after the construction of this road that the way between Vienna and Venice was wide open. After that time, the traffic from the North to the South increased, the East-West orientation of the original Maribor settlement (in line with the Drava River) points to the significance of the Drava River and the Drava road from Hungary towards Carinthia for the formation of a settlement and for the whole area. If we follow the analysis of Otmar Pickl, we can assume the formation of the Maribor suburban settlement even in the period up to the 12th century, in which the North-South connection then gained in importance; until that time, the EastWest routes in Styria were predominant, with one of the most important ones being the so-called Drava road, which in the earliest period avoided the Drava forest, and bypassed the area over the Radelj crossing. ${ }^{14}$ The Drava road or at that time also called "Royal Road" ("via regia") ${ }^{15}$ retained its great importance (wine trade as the most important trade in Maribor in the Middle Ages was largely conducted along this road, or along the river Drava), which is also shown by the fact that many Carinthian monasteries, as well as the Dioceses of Krško and Lavant had their own properties (predominantly vineyards) in the vicinity of Maribor, that they also had their own courts in the city, and that in the sources there is a lot of data on individual privileges that these institutions managed to gain or were trying to obtain. In the 11th and especially in the $12^{\text {th }}$ century, when on the basis of the distribution of the findings of the Friesach coins in Friuli and especially in Hungary, we can establish up to where the Carinthian commercial ties extended, the majority of which spread along the Drava River, Maribor, for which we can conclude that it developed into a non-agricultural settlement precisely at that time, was much less important than Ptuj, which was the main entrance to the Hungarian Kingdom for the German and Friulian merchants. Otmar Pickl notes that the Jews from Ptuj were the main distributers of the Friesach coins throughout the Hungarian Kingdom. ${ }^{16}$

The analysis of Maribor's relations with other cities and provinces showed, ${ }^{17}$ that in the contacts of the cities of the Slovenian Styrian with other cities the northern and western directions prevailed. A quick analysis of the population origin shows close contacts of Maribor with the northern Styrian cities, and, towards the West with Carinthia, which is very much significant for the described position of Maribor, as a centre of the wine-growing region and especially of the wine trade. In Maribor, we meet both Maribor citizens in the service of the Carinthian church institutions, as well as people who came to Maribor from Carinthia, acquired

\footnotetext{
14 Pickl, Handel und Verkehr, 327-330. Cf. also: Kosi, Potujoči srednji vek, in particular 227-231.

15 1278, 2 May, Dravograd; MDC 5, No. 344, 214/5. and 1278, 3 May Velikovec; MDC 5, No. 345, $215 / 6$.

16 Pickl, Handel und Verkehr, 329. Miha Kosi, Potujoči srednji vek, 32-36.

17 Tone Ravnikar, "Kraji na slovenskem Štajerskem in Maribor v srednjem veku", Studia Historica Slovenica 6 (2006), no. 2-3: 279-296.
} 
citizenship rights and occupied important positions in the city self-governing institutions, or at least possessed a certain property. Without trying to give detailed evidence thereof, let me just state some typical examples. Already in 1278, the citizen Gerloh ${ }^{18}$ from Völkermarkt owned estates in the vicinity of Maribor (more precisely, the vineyard in Počehova), and in 1348 Nikolai "der Payer," the citizen from Strassburg in Carinthia, owned a vineyard near Maribor, ${ }^{19}$ only a few decades later, Peter Sweinörl and Ivan Brentzel ${ }^{20}$ the citizens from Sankt Veit in Carinthia, traded wine; in Kamnica Ivan Kribitz from Friesach in Carinthia had vineyards, which he rented to the tailor Jakob from Völkermarkt; ${ }^{21}$ Friderik from Spittal (1397), Reinhard from Strassburg (1423) and Nikolai from Himmelberg $^{22}$ are also mentioned as the citizens of Maribor, and the list is even longer.

It can be concluded that the contacts with the northern part of Styria, Salzburg, Carinthia and the Austrian Land, etc., were important and even prevailed in certain periods and in certain areas. At this point, I would like to point out the works of Ferdinand Tremlin, who in his economic and historical texts also addressed the toll station Plač, North of Maribor; his findings excellently show the importance and quantity of traffic, both commercial and other, from Maribor to the North. ${ }^{23} \mathrm{~A}$ similar picture is also shown by the toll-book for Vransko, probably the most important toll station along the so-called Ljubljana road in the Savinjska region. ${ }^{24}$ It is also necessary to recall the salt border, i.e. the border between the stone salt, i.e. Salzburg (the so-called Aussee) and the sea salt, which ran mainly along the Drava River, and on the border of which Maribor was located. At the end of the 14th century, more precisely in 1390, the Duke Albrecht determined the salt border, which considering the area referred to in the paper, was described in a way that the area of ausseic salt trade extended to Slovenska Bistri$\mathrm{ca}$, to the city and with some indefinite addition "Whereto it went in old times." 25 However, such a border course was not realistic, as the sea salt trade pushed the border upwards. The actual border ran more or less along the Drava River, and with its crossings over the Drava River (e.g. in the area of Ptuj, to which the sea

18 1278; in: GZM II/42.

19 1348, January, 11. Krka na Koroškem; in: GZM IV/43.

20 1375, December, 23.; in: GZM V/19.

21 1435, October, 21.; in: GZM VI/62.

22 Cf.: Jože Mlinarič, "Maribor od začetkov do sredine 18. stoletja”, in: Maribor skozi stoletja, razprave I., eds. Jože Curk, Bruno Hartman, Jože Koropec (Maribor: Obzorja, 1991) (hereinafter: Mlinarič, "Maribor od začetkov"), 149.

${ }^{23}$ Ferdinand Tremel, "Der Verkehr über den Platsch in der frühen Neuzeit", Zeitschrift des historischen Vereines für Steiermark 48 (1957): 108-144.

${ }^{24}$ Othmar Pickl, "Das Mautbuch von Vransko/Franz von 1584/85", in: Erzeugung, Verkehr und Handel in der Geschichte der Alpenländer, eds. Franz Huter, Herbert Hassinger (Innsbruck: Wagner, 1977), 307 et. seq.

25 1390, March,6. Vienna, copy in AUR StLA, no. 3692 c. 
salt reached) is reminiscent of the course of today's state border. Sergij Vilfan also rightly contemplated that at the beginning of the 9th century the salt trade led to the determination of the church border between the Aquilean Patriarchate and the Salzburg Archdiocese. ${ }^{26}$ I would like to draw attention to the well-known fact that the borders of the sea and the stone (Aussies) salt trade are almost identical with the borders to which the so-called Kranj's currency exchange system was applicable. ${ }^{27}$ The contacts with the northern parts of the Duchy of Styria, are also evident from the sources. Thus, a document with which Ulrik "der Pyrer," a citizen from Bruck an der Mur and Henrik der "Lynccer," a citizen from Leoben, issued a debt letter ${ }^{28}$ to Dominique Masskke, a citizen from Maribor, is known; in 1402, Tomaz "der Reyagkh" from Ernau near Mautern sold his vineyard, which he had at Malečnik, ${ }^{29}$ and in 1478, Peter Kormuess, the city judge of Bruck an der Mur appealed to the Styrian Duke that Erazem Regensoder, a Radgonian citizen, had unjustly usurped his house in Maribor. Michael from Neumarkt at Judenburg (1401), Pavel from Graz (1402) and Ivan from Halbenrain (1499) are known as the citizens of Maribor. There may be more examples that prove close contacts between cities and citizens of individual cities, and the stated ones should support the mentioned facts.

Maribor also attracted (mainly) merchants from more distant places, who for some reason (usually because of trade links) came to Maribor and then remained in it. Thus, from the sources in 1348 a certain Dominik Maeschk (der Walich) was known, the son of the late Vidus of Friuli (Venzon/ Pušja village), in 1355, also from Venzon, a certain Jakob, the son of the late Viland was mentioned, and in the 15th century a certain Nikolaj Walch was even the city judge of Maribor. Especially the references to both Friulians from Venzon show the importance of the East-West links across the Drava River, Villach to Friuli, which ran through Venzon and was opened for traffic through Val Canale in the 13th century; ${ }^{30}$ an important bridge was built over the river Tagliamento already in the Middle Ages, which enabled the mentioned physical links. In addition to the aforementioned personal contacts of Maribor with places in Carinthia and, last but not least, with Carinthian monasteries (the Cistercian monastery of Vetrinje, the Benedictine monastery of St. Paul, and Praepositus's House in Doberla vas) ${ }^{31}$ and

\footnotetext{
26 Sergij Vilfan, "K zgodovini kmečkega kupčevanja s soljo”, Kronika 10 (1962), band 3, p. 133.

27 Sergij Vilfan, Pravna zgodovina Slovencev: Od naselitve do zloma stare Jugoslavije (Ljubljani: Sloven. Matica, 1961): 307-309.

28 1347, June, 8.; in: GZM IV/40.

29 1402, September, 27.; in: GZM V/84.

30 Herbert Hassinger, "Zollwesen und Verkehr in den österreichischen Alpenländern bis um 1300", Mitteilungen des Instituts für österreichische Geschichtsforschung 73 (1965): 308, footnote 53.

31 See: Jože Mlinarič, “Posest vetrinjske opatije na Štajerskem (ok. 1145-1786)”, Časopis za zgodovino in narodopisje 52 (1981): 38-58; Mlinarič, "Maribor od začetkov", 158.
} 
the Krško Diocese, together with the original settlement designed from East to West, undoubtedly prove that Maribor was set up primarily because of this connection, which was established on the so-called Drava road, and to foster the North-South connection on the so-called Viennese and Ljubljana roads, which ultimately prevailed as late as at the end of the 14th century, probably only after the final passing of Trieste into the hands of the Habsburgs in 1382. When assessing the significance of this route, not only in relation to the history of the city of Maribor, but also in a much wider context, it must be borne in mind that, on this route a border tollhouse was established between Carantania and the East, probably already at the end of the early Middle Ages, which must have been operating at least since the middle of the $12^{\text {th }}$ century, and that already in the 12th century, the Traberch nobles also set up Dravograd as the most important urban market settlement in this area, ${ }^{32}$ and that, as I already pointed out, the establishment of the Maribor market settlement is assumed already before 1180; it is possible that the urban settlement, which was not yet called Maribor, had existed even in the beginning of the 12th century. ${ }^{33}$ In order to attest to the whole complexity of the relations between the citizens of different towns, or better, their intertwining, I will only list one document at the end of this cluster that perfectly reflects all the mobility, ambition and, from today's perspective, the internationality of the connections of the medieval bourgeoisie. In 1438, a document was published, which in its content is actually not special. It refers to the transfer or selling some property among relatives. What is interesting is the family realtions of the persons mentioned in the document. The relatives of Erazem Schmitzperger from Halstatt, his son-in-law Ivan Müllej from Maribor, the other son-in-law Wencel "dem Döprer" from Judenburg, and his late father-in-law Valentin Höhl, a citizen from Rottenmann ${ }^{34}$ are stated in the document. The issue is about real dynastic relations and about occupying strategic positions in the cities located along the route connecting the southern and northern Styria and the Salzburg region.

Whereas the frequent and much wide-spread contacts with both the northern German and the western Friulian regions are widely mentioned in the sources, almost no personal contacts (both family and commercial links) between Maribor and other Slovenian Styrian cities and the East are recorded. However, one cannot state that they were non-existent. Professor Voje who researched the links between the Dubrovnik merchants and the Slovene cities provided us with a little less known piece of data. The first piece of information about the presence of a Dubrovnik merchant in the area of today's Slovenia is linked precisely to

32 Cf: Miha Kosi, Začetki mesta Slovenj Gradec, Kronika 56 (2008): 146-147, in which the author argues that Dravograd had a city character already at the end of the 12th century and that it was set up by the Ottokars of Styria as a competitive urban settlement in response to the loss of Slovenj Gradec around 1174.

33 Cf. quotation in the footnote 10.

34 1438, January, 14.; GZM VI/66. 
Maribor. In 1441, Michael Allegretti, ${ }^{35}$ the merchant from Dubrovnik, turned to King Frederik in writing because of the damage amounting to 800 ducats he had suffered in Maribor, which he wanted to have recovered. Allegretti probably travelled along the so-called Ljubljana road through Maribor, and was probably aiming further to the North. The amount of damage, however, indicates that he must have traded commodities of great value. ${ }^{36}$ The majority of the routes travelled by the Dubrovnik merchants did not run through Maribor but through Ptuj. The fact was mentioned in a letter sent to the Emperor Maximilian in 1505 by the citizens from Dubrovnik, in which they stated that their merchants often came to the Kingdom and to the places of his Majesty and especially to the territory of Ljubljana and Ptuj ("praesertim ad terras Gliubiane et Petovie") with their commodities, where they experienced major problems. In this context, they particularly resented the right to a mandatory storage that was applicable practically in all the cities. In particular, the city of Ptuj was subjected to the order of Emperor Maximilian of 1503, according to which Italian, Hungarian and other foreign merchants, traveling with oxen hide and other commodities from Hungary through Ptuj should store these goods in Ptuj and stay there until the following fair. Restrictions on foreign merchants and the right to a mandatory storage were already provided in the Ptuj Statute; thus, it was an old right of the city, which was only approved of and specified in later periods. For Dubrovnik merchants (and of course not only for them), such an obstacle was, as they wrote in the complaint, a waste of time and additional damage caused to goods ${ }^{37}$. The fact that the cities of Ljubljana and Ptuj, as well as the ones they frequented, were mentioned, shows that the East-West connection and the connection with Hungary was more important for the merchants from Dubrovnik than the connection North-South, or the connection with Germany. The importance of the route to Hungary was almost certainly increased for the Dubrovnik citizens after the expansionist Ottoman State prevented direct links between Hungary and Dubrovnik through Bosnia.

From the sources related to the city of Maribor one more piece of data is known, which does not directly refer to trade links between Styria and Croatian lands, but may be understood as such. On February 21, 1341, the Maribor city judge Willian, along with the City Council, informed Bartolomeo Gradenigo, the Doge of Venice, that Brigita, a widow after her deceased husband Janez Cirol, who

\footnotetext{
35 He was a member of the family that originated from the family of the Dubrovnik merchant Radoslav Brajkovic. One of his sons is called Christophorus Raddosslai Brajcovich dictis Gradich. Later, the father's name Radoslav was renamed into Latin Allegrettus. See: Ignac Voje, "Trgovski stiki med Dubrovnikom in slovenskimi kraji v drugi polovici 15. in v začetku 16. stoletja”, Časopis za zgodovino in narodopisje 40 (n.v. 5) (1969), Bašev zbornik, p. 221, footnote 3.

${ }^{36}$ Ignacij Voje, Poslovna uspešnost trgovcev v srednjeveškem Dubrovniku (Ljubljana: Znanstveni inštitut Filozofske fakultete, 2003) (hereinafter: Voje, Poslovna), 212.

37 Voje, Poslovna, 217.
} 
had died on Crete, turned to him, asking together with her daughters for his intervention in the acquisition of the property that the deceased husband had had on him at the time of his death. The mentioned property was deposited in the city Rethymon on Crete. The judge William appointed the nobleman Ulrich Mariborski to be the widow's representative; the latter set off for Venice with the authorization and saw to the matter through his Venetian contacts on Crete. ${ }^{38} \mathrm{In}$ May Ulrich was apparently already in Venice, where a document was issued by which Stefan de Franchino, a Venetian notary public, confirmed that Janez Cirol from Maribor and Nikolai from Hungary, who had both been on the pilgrimage to the Holy Sepulcher, had died on Crete, in the house of Henrik Mercari, a local citizen of German origin, and that they had money and other commodities on them at the time of death. All their belongings were deposited in the town house in Rethymon. Janez's legacy amounted to 105 florins and 6 pennies and was left to Johannes Grioni, which was handed over to Ulrich Mariborski in Venice, who then stated that the widow and daughters no longer had any requests with regard to the legacy of the deceased. ${ }^{39}$ Both documents are much revealing. We learn from them that the Maribor merchant Janez Cirol must have been a wealthy man considering the amount of 105 florins that was high; the mentioning of other commodities that the two pilgrims had carried suggests that, in addition to a pilgrimage, they had mainly business interests that directed their course of action. Both documents also mention the type of financial transactions - the amount of money was paid out in Venice and was guaranteed by the Venetians or their commercial bonds; thus, it was no longer necessary to physically transport money from Crete to Venice. The most important research data is the presence of Nikolai from Hungary. His identity cannot be stated with certainty. However, we can assume, that both Janez Cirol and Nikolai were at least business partners, if not personal acquaintances and friends, which most logically explains their joint pilgrimage. Most likely, they were brought together by common business operations, along with personal ties. The "de Hugaria" mark itself does not disclose a more accurate location of the referred merchant. However, it is at least equally probable that he was from the territory of the present-day Croatia or from the territory of today's Hungary. But, as mentioned, he could not be precisely located.

A very similar situation as for Maribor is provided in the documents for other Styrian cities. For virtually all cities, it is generally possible to establish that they were primarily local craft centres, in which the transit trade and trade of local importance prevailed. In such places, of course, we do not expect a greater volume of foreign merchants. Maribor, however, partly deviates from the standard concept, which was "the second capital city" in Styria, in which the provincial lord repeatedly stopped, performing his judicial and other provincial assign-

38 GZM IV/20.

39 GZM IV/21. 
ments, convening the provincial councils, and so forth. In the first half of the 15th century Celje started to change its character when the Counts of Celje were systematically transforming Celje it into their new capital; ${ }^{40}$ however, the process was of short duration, since it was brutally interrupted by the assasination of Ulrich II of Celje on November 9, 1456, in Belgrade.

Of all the places, Ptuj was one of the most important trade centers, to which big commercial institutions and, probably, banks were oriented. The materials about Ptuj, however, attest to almost a complete absence of merchants from Croatian lands from the markets of the Styrian cities. The materials reveal that trade was controlled by retailers from the North, to which also most of the business and personal contacts extended. This is very clearly witnessed by the well-known fact that at the end of the 15th century, due to the constant Turkish threat, as well as the Hungarian-Habsburg Wars ${ }^{41}$ the wealthiest merchants from Ptuj moved to Imperial Nürenberg and were practically immediately classified among the wealthiest Nurenberg citizens; Hans Thurmer was labeled as "rich" in the local documents, and comparable wealth is also shown by Peter and Heinrich Meichner, who left Ptuj after the devastating Turkish invasion of 1472, and transferred wealth amounting to 70,000 guilds with them.

Another merchant, Ladislav Swetkowitz, remained in Ptuj, but managed to transfer capital in the amount of 27,000 florins to Regensburg and Nürnbeg to safety. ${ }^{42}$ This was largely due to the fact that Ptuj was an international trading centre, in which there was the main hub for handling Hungarian hide and Hungarian livestock, mainly oxen and wethers. ${ }^{43}$ The preserved sources, reports, promissory notes, etc. prove a typical exchange trade, where the Hungarian livestock and hide were exchanged for cloth from Germany (Aachen) and Poland and for various Venetian commodities. As for the origin of the merchants they were all from German and Italian districts. ${ }^{44}$ Even those rare Hungarian merchants, whose names are stated in the sources, originated mainly from the German territory, among them also one of the most famous (whole)sellers from Budim, Matthias Herber, who came from Nürenberg. ${ }^{45}$ Interestingly, the role of Hungarian mer-

40 Cf. e.g.. Sergij Vilfan, “Glose k zgodovini srednjeveškega Celja”, Kronika 32 (1984), no. 1: 15-19. Miha Kos, "Dežela ki je ni bilo: Posavinje med Kranjsko in Štajersko od 11. do 15. stoletja”, Studia Historica Slovenica 8 (2008), no. 2-3: 527-546.

41 Štih-Simonitti, Na stičišču, 201-207.

42 Othmar Pickl, "Pomen Ptuja kot mednarodnega trgovskega mesta od 14. do 17. stoletja", Ptujski zbornik 6/1, (1996): 470 et seq. (hereinafter: Pickl, “Ptuj”).

${ }^{43}$ Othmar Pickl, "Pettau - ein internationaler Handelsplatz des 15. und 16 Jahrhunderts", Zeitschrift des Historisches Vereines für Steiermark 62 (1971): 87 et seq.

${ }_{44} \mathrm{Za}$ italijanske trgovce na Ptuju prim.: Ferdo Gestrin, "Prispevek h gospodarski zgodovini Ptuja v prvi polovici 16. stoletja”, Časopis za zgodovino in narodopisje 40 (n.v. 5) (1969): 228-235.

45 Pickl, "Ptuj", 485, footnote 38. 
chants in livestock and hide trade is generally widely recognized, but not evident from the city archives. In the sources not even one definite trader from Hungary or from Croatia is mentioned.

This is also evidenced by the granting of the storage law to the city of Ptuj by Emperor Maximilian I in 1503. In this law, the Emperor specified that merchants who brought hide or other commodities from Hungary to Ptuj should store them. They were only allowed to sell the commodities on the following fair day (on the Pentecost or on St. Ozbolt Day - August 5). On the other hand, the citizens of Ptuj, Germans or Italians (!) were always allowed to sell their commodities; thus, it obvious that there were Germans, the Styrian citizens, as well as the Austrians, the Carinthians, the Bavarians ... and the Italians among the Ptuj citizens. ${ }^{46}$ Merchants from Hungary, however, were certainly much limited in trading by the ban on trading across today's Slovene regions to Italy, against which the King of Matthias Corvin failed to succeed in his appeal to the Emperor Frideric III in $1479 .{ }^{47}$

In any case, we can generally conclude that Ptuj, as an international trade centre, benefited from the integration of Trieste in the Habsburg property, since the Habsburgs showed an increased interest in the promotion of trade along the so called Karst Road or the Ljubljana Road, that ran to Hungary through Ptuj; further Ptuj also benefited from the integration of the former Posavinje, a Celje region, which came into possession of the Habsburgs after the extinction of the prince's family after 1456 .

The sources about Ptuj, however, allow us to expose one series of commercial contacts, which was undoubtedly in the hands of Croatian merchants, i.e. a fish trade. The first preserved Statute of Ptuj of $1376,{ }^{48}$ as well as its approval by the Salzburg Archbishop Bernhardt von Rohr (1466 - 1482) in $1466^{49}$ and the new Statute, which the city received in $1513,{ }^{50}$ placed a special emphasis on the rights related to the referred trade. In substance, the decisions did not change over time, which attests to the fact that this old right was applied for at least 200 years. According to the Statute of 1513, "if a foreigner from Hungary comes with fish to Ptuj, he should be selling them to the citizens for three days in retail and whole-

\footnotetext{
${ }^{46}$ More Italian merchants were spotted in Ptuj from the end of the 15th century onwards (Mosconi, Lanthieri), and in greater numbers in the 16th century (Martinengo, Moffet, de Leidi). Cf..: Gestrin, "Prispevek", 231 et seq.

47 Joseph Chmel, eds, Monumenta Habsburgica. Sammlung von Actenstücke und Briefen zur Geschichte des Hauses Habsburg in dem Zeitraume 1473 - 1576 III. Band (Wien: Kaiserl-Königlischen Hof-und Staatsdruckerei 1858), 236-239.

48 Marija Hernja Masten et all.. eds., Statut mesta Ptuj, študijska izdanja (Maribor: Primoz Premzl, 1998).

49 1466, 6 July, Salzburg; transcript in AUR StLA, no. 7133b.

50 Masten, Statute of the City of Ptuj.
} 
sale. But if he cannot sell them within three days, he can sell them to whom he wants or take them to further destination. ${ }^{51}$ " As already mentioned, the same article as per content can be found in both older documents. The reference is to a trade with perishable goods, for which we can assume that they were brought to Ptuj from a relatively close destination.Therefore, it is most likely that the reference is to the merchants who were supplied with fish from fishermen by the river, almost certainly by the Drava River; taking this fact into consideration, the merchants were probably from Varaždin and its surroundings, from where they delivered fish to Ptuj, and apparently failed to catch enough fish to meet all the needs. The repetition of the same substantive clause attests to the regular appearance of those merchants in Ptuj. Unfortunately, we do not know of a single document that would allow for better highlighting and, above all, personalizing those contacts.

However, we need to point out one more thing. Even though it was established in the research conducted by Ferdo Gestrin on trade contacts between Slovenian provinces and the neighboring countries that the trade route that had run from Zagreb to the West past Brežice, Novo mesto, Ljubljana, and Postojna towards Italy was very important and frequented, ${ }^{52}$ the documents about Brežice by no means attest to that, not even with a single hint.

In conclusion, let me point out that contrary to the expectations at the beginning of the research, there are very few recorded direct contacts between merchants from the Croatian lands and the cities of the Styria region. With the exception of the Dubrovnik merchant Allegretti and possibly Nikolai from Hungary, who accompanied the Maribor trader Cirol, we do not know of any documents that would attest to the undoubted presence of a particular Croatian trader in the considered region. This may largely be due to a lack of the kept resources. However, we are convinced that such unavailability of resources does reflect the real situation, since due to the fierce competition of big trading houses from the German and Italian territories, and considering the apparently not so small a number of domestic "super merchants," at least in Ptuj, there was actually no room for the operation of other commercial houses or individuals. There can be no doubt that the weekly presence of small merchants - chandlers - from the Croatian territory was much bigger; however, we can assume that they were mainly or more or less exclusively, small, relatively unimportant merchants in the wholesale trade.

\footnotetext{
51 Marija Hernja Masten, Dušan Kos, Statut mesta Ptuja 1513 (Ptuj; Ljubljana: Zgodovinski arhiv; Znanstveno raziskovalni center Slovenske akademije znanosti in umetnosti, 1999), art. 128, p. 155.

52 Cf.: Ferdo Gestrin, Slovenske dežele in zgodnji kapitalizem (Ljubljana: Slovenska matica, 1991), 103 et seq.
} 


\section{Archival and published sources}

Austria - Graz - Steiermärkisches Landesarchiv - Allgemeine Urkundenreihe.

Chmel, Jospeh. Monumenta Habsburgica. Sammlung von Actenstücke und Briefen zur Geschichte des Hauses Habsburg in dem Zeitraume 1473 - 1576. III. Band. Wien: Kaiserl-Königlischen Hof-und Staatsdruckerei, 1858.

Hernja Masten, Marija; Kos, Dušan. Statut mesta Ptuja 1513. Ptuj; Ljubljana: Zgodovinski arhiv; Znanstveno raziskovalni center Slovenske akademije znanosti in umetnosti, 1999.

Mlinarič, Jože, ed. Gradivo za zgodovino Maribora, zv. 2: listine 1260 - 1309. Maribor: Pokrajinski arhiv, 1976.

Mlinarič, Jože, ed. Gradivo za zgodovino Maribora, zv. 4: listine 1336 - 1370. Maribor: Pokrajinski arhiv, 1978.

Mlinarič, Jože, ed. Gradivo za zgodovino Maribora, zv. 5: listine 1371 - 1414. Maribor: Pokrajinski arhiv, 1979.

Mlinarič, Jože, ed. Gradivo za zgodovino Maribora, zv. 6: listine 1416 - 1445. Maribor: Pokrajinski arhiv, 1980.

Wießner, Hermann, ed. Monumenta historica ducatus Carinthiae. Geschichtliche Denkmäler des Herzogthumes Kärnten. Bd. 5: Die Kärntner Geschichtsquellen 1269 - 1286. Klagenfurt: Kleinmayr, 1956.

\section{Literature}

Curk, Jože. Trgi in mesta na slovenskem Štajerskem, Maribor: Obzorja, 1991.

Gestrin, Ferdo. "Prispevek h gospodarski zgodovini Ptuja v prvi polovici 16. stoletja”. Časopis za zgodovino in narodopisje 5 (1969): 228-235.

Gestrin, Ferdo. Slovenske dežele in zgodnji kapitalizem. Ljubljana: Slovenska matica, 1991.

Hassinger, Herbert. "Zollwesen und Verkehr in den österreichischen Alpenländern bis um 1300". Mitteilungen des Instituts für österreichische Geschichtsforschung 73 (1965): 292-361.

Kos, Dušan. Kdor z mestom ne trpi naj se z mestom ne krepi. Ljubljana: Ministrstvo za kulturo, Uprava Republike Slovenije za kulturno dediščino, 1998.

Kosi, Miha. Potujoči srednji vek: Cesta, popotnik in promet na Slovenskem med antiko in 16. Stoletjem. Ljubljana: ZRC SAZU, Založba ZRC, 1998.

Kosi, Miha. "Dežela ki je ni bilo: Posavinje med Kranjsko in Štajersko od 11. do 15. stoletja". Studia Historica Slovenica 8 (2008), no. 2-3: 527-546. 
Kosi, Miha. “Začetki mesta Slovenj Gradec”. Kronika 56 (2008), no. 2: 131-164.

Mlinarič, Jože. "Posest vetrinjske opatije na Štajerskem (ok. 1145-1786)". Časopis za zgodovino in narodopisje 52 (1981): 38-59.

Mlinarič, Jože. "Maribor od začetkov do sredine 18. stoletja”. In: Maribor skozi stoletja, razprave I., eds. Jože Curk, Bruno Hartman, Jože Koropec. Maribor: Obzorja, 1991.

Muchar, Albert. Geschichte des Herzogthums Steiermark VI. Graz, 1859.

Pickl, Othmar. "Das Mautbuch von Vransko/Franz von 1584/85”. In: Erzeugung, Verkehr und Handel in der Geschichte der Alpenländer, eds. Franz Huter, Herbert Hassinger. Innsbruck: Wagner, 1977.

Pickl, Othmar. "Pettau - ein internationaler Handelsplatz des 15. und 16 Jahrhunderts". Zeitschrift des Historisches Vereines für Steiermark 62 (1971): 269.

Pickl, Othmar. "Handel und Verkehr in der Steiermark zur Zeit der Traungauer". In: Das Werden der Steiermark, ed. Gerhard Pferschy. Graz; Wien; Köln: Styria, 1980.

Pickl, Othmar. "Pomen Ptuja kot mednarodnega trgovskega mesta od 14. do 17. stoletja”. Ptujski zbornik 6 (1996), no. 1: 463-490.

Ravnikar, Tone. "Kraji na slovenskem Štajerskem in Maribor v srednjem veku". Studia Historica Slovenica 6 (2006), no. 2-3: 279-296.

Ravnikar, Tone. "Mestne elite v srednjeveških Brežicah in Sevnici". In: Mestne elite $v$ srednjem in zgodnjem novem veku med Alpami, Jadranom in Panonsko nižino, ed. Janez Mlinar, Bojan Balkovec. Ljubljana: Zveza Zgodovinskih Društev Slovenije, 2011.

Spreitzhofer, Karl. Georgenberger Handfeste. Entstehung und Folgen der ersten Verfassungsurkunde der Steiermark. Graz : Verlag Styria, 1986.

Štih, Peter. "Celjski grofje, vprašanje njihove deželnoknežje oblasti in dežele celjske”. In: Grafenauerjev zbornik, ed. Vincenc Rajšp et all. Ljubljana: Slovenska akademija znanosti in umetnosti; Znanstvenoraziskovalni center SAZU; Filozofska fakulteta v Ljubljani; Pedagoška akademija v Mariboru, 1996.

Štih, Peter; Simonitti, Vasko. Na stičišču svetov. Ljubljana: Modrijan 2009.

Tremel, Ferdinand. "Der Verkehr über den Platsch in der frühen Neuzeit". Zeitschrift des historischen Vereines für Steiermark 48 (1957): 108-144.

Vilfan, Sergij. Pravna zgodovina Slovencev (od naselitve do zloma stare Jugoslavije). Ljubljana: Slovenska matica, 1961.

Vilfan, Sergij. "K zgodovini kmečkega kupčevanja s soljo”. Kronika 10 (1962): $1-12$. 
Vilfan, Sergij. “Glose k zgodovini srednjeveškega Celja”, Kronika 32 (1984), no. 1: $15-19$.

Voje, Ignac. "Trgovski stiki med Dubrovnikom in slovenskimi kraji v drugi polovici 15. in v začetku 16. stoletja”. Časopis za zgodovino in narodopisje 40 (1969): 221-227.

Voje, Ignac. Poslovna uspešnost trgovcev v srednjeveškem Dubrovniku. Ljubljana: Znanstveni inštitut Filozofske fakultete, 2003.

Weiss, Norbert. Das Städtewesen dr Ehemaligen Untersteiermark im Mittelalter. Graz: Im Selbstverlag der Historischen Landeskommission für Steiermark, 2002. 
Tone Ravnikar*

\section{Trgovačke veze hrvatskih zemalja s gradovima Slovenske Štajerske}

\section{Sažetak}

Tema je ovoga članka proučiti i predstaviti postojeće trgovačke veze između stvarnih trgovaca hrvatskoga i slovensko-štajerskoga prostora. Autor se kao polazišnom točkom poslužio arhivskom građom gradova današnje slovenske Štajerske. Pritom je najprije trebalo definirati pojam Slovenske Štajerske te ga geografski, politički i demografski odrediti. Pokazalo se da postoje velike razlike između Podravlja i Posavlja. Općenito možemo ustanoviti da je Posavlje bilo usmjereno na trgovinu između Zagreba i Italije, dok je Podravlje bilo više usmjereno na trgovinu između Mađarske i Italije. U oba je slučaja konačni cilj trgovaca bila Italija kao glavni uvoznik robe s istoka. Mnogo je teži zadatak bio ući u trag stvarnim pojedincima koji su se bavili trgovinom. Arhivska nam građa, naime, ne govori gotovo ništa o trgovcima koji su u Štajersku dolazili $s$ istoka.

Iznenađuje nas činjenica da pregled arhiva kneževskoga grada Maribora, kao i salzburškoga grada Ptuja te Celja kao središta nastajućega teritorija celjskih grofova/kneževa, čiji glavni strateški element predstavljaju upravo mađarski/hrvatski posjedi, službe odnosno titule, ukazuje na gotovo identičnu odsutnost konkretnih veza s hrvatskim trgovcima. Građa nam pruža nekolicinu manjih iznimaka. Poznat nam je samo dubrovački trgovac Mihael Allegreti, koji je 1441. godine bio u Mariboru na poslovnome putovanju, a uz njega možemo, uz veliku dozu opreza i skepse, spomenuti trgovca s hrvatskoga prostora Nikolaja iz Ugarske, koji se 1341. godine na hodočašću i poslovnome putu nalazi u pratnji mariborskoga trgovca po imenu Cirol. To su jedina svjedočanstva o postojećim pojedincima. Oba ptujska statuta omogućuju nam rekonstrukciju još jedne vrste rijetkih trgovačkih veza između Ptuja i hrvatskih trgovaca koji su u Ptuju prodavali ribu. Riječ je o praksi koja se na kontinuitetu održavala dvjesto godina. Nažalost, ne postoji dokument koji bi te hrvatske trgovce, za koje pretpostavljamo da su bili iz Varaždina i/ ili njegove okolice, detaljnije predstavio, na primjer poimence, pripadajućom količinom i vrstom prodane ribe, njihovim utrškom i tako dalje.

Općenito možemo ustanoviti da su monopol nad trgovinom $s$ istokom najprije imale takozvane njemačke, a zatim talijanske trgovačke obitelji. Zbog iznimno visoke zarade o kojoj svjedoči građa iz Nürnberga, gdje su se zatekli trgovci koji su koncem 15. stoljeća odbjegli iz Ptuja i tamo odmah stupili u najviši krug gradskih patricija, takvo je ustrajanje u monopolu nad trgovinom potpuno razumljivo. Razlog za takvu odsutnost hrvatskih trgovaca u velikoj su mjeri nedvojbeno nedovoljno sačuvani izvori. Ipak, uvjereni smo da u ovome slučaju takav nedostatak izvora odražava pravo stanje jer u oštroj konkurenciji velikih trgovačkih obitelji njemačkoga i talijanskoga prostora i uz, očito,

Tone Ravnikar, Filozofska fakulteta, Univerza v Mariboru, Koroška 160, 2000 Maribor, Republika Slovenija, E-mail adresa: anton.ravnikar@um.si 
ne tako zanemariv broj domaćih "supertrgovaca," barem u Ptuju, nije bilo mnogo prostora za djelovanje drugih trgovačkih obitelji ili pojedinaca. Nema nikakve dvojbe da je tjedna prisutnost malih trgovaca - kramara - s hrvatskoga prostora bila mnogo veća, ali riječ je o pretežito te više ili manje isključivo malenim, relativno nevažnim, trgovcima u kontekstu trgovine na veliko koja je cvjetala.

Ključne riječi: Slovenska Štajerska, Hrvatska, srednjovjekovna trgovina, Maribor, Ptuj 